\title{
Pengaruh Pemberian Pupuk Organik Granul terhadap Pertumbuhan dan Hasil Tanaman Padi (Oryza sativa L.) Varietas Ciherang pada Lahan Rawa Lebak
}

\section{(Effect of Organic Fertilizer Granul to Growth and Yield of Paddy (Oryza sativa L.) Ciherang Variety on Lebak Wetland)}

\author{
Ahmad Riyadi \\ Program Studi Agroteknologi, Sekolah Tinggi Ilmu Pertanian Amuntai \\ riyadiahmad577@yahoo.com
}

\begin{abstract}
ABSTRAK
Padi merupakan bahan makanan yang menghasilkan beras. Bahan makanan ini merupakan makanan pokok bagi sebagian besar orang Indonesia. Bahkan sebagai bahan makanan pokok, padi dapat diganti atau disubtitusi oleh bahan makanan lain, tetapi padi mempunyai nilai tersendiri untuk orang yang terbiasa makan nasi dan tidak dapat dengan mudah digantikan oleh bahan makanan lainnya. Penelitian ini bertujuan (i) mengetahui pengaruh, dan (ii) mendapatkan dosis terbaik pupuk organik granul terhadap pertumbuhan dan hasil tanaman padi Varietas Ciherang di lahan rawa lebak. Penelitian ini dilaksanakan di Desa Harusan, Kecamatan Amuntai Tengah, Kabupaten Hulu Utara, dari bulan Februari - Mei 2011. Penelitian ini menggunakan Rancangan Acak Kelompok (RAK) faktor tunggal. Faktor yang diteliti adalah dosis pupuk organik granul sebanyak 5 taraf yaitu : $g_{0}: 0$ ton.ha ${ }^{-1}, g_{1}: 1$ ton.ha $a^{-1}$ setara dengan atau $8,571 \mathrm{~g}$ per rumpun atau 0,3 $\mathrm{kg}$ per petak. $\mathrm{g}_{2}: 2$ ton.hal setara dengan $17,142 \mathrm{~g}$ per rumpun, atau $0,6 \mathrm{~kg}$ per petak. $\mathrm{g} 3: 3$ ton. $\mathrm{ha}^{-1}$ setara dengan $25,714 \mathrm{~g}$ per rumpun, atau 0,9 $\mathrm{kg}$ per petak. $\mathrm{g} 4: 4$ ton.ha $\mathrm{a}^{-1}$ setara dengan 34,285 g per rumpun, atau 1,2 kg per petak. Faktor yang diteliti adalah dosis pupuk organik granul sebanyak. Hasil penelitian menunjukan bahwa perlakuan dosis pupuk organik granul tidak berpengaruh terhadap tinggi tanaman, banyak anakan, tetapi perlakuan berpengaruh nyata pada jumlah gabah isi per rumpun. Perlakuan dosis pupuk organik granul 2 ton.ha ${ }^{-1}$ setara dengan 17,142 g per rumpun merupakan dosis terbaik terhadap jumlah gabah isi per rumpun.
\end{abstract}

Kata kunci: Padi, pupuk, organik, granul, rawa.

\section{ABSTRACT}

Rice is a food that produces rice. This food is a staple food for most Indonesians. Even as a staple food, rice can be replaced or substituted by other food ingredients, but rice has its own value for people who are accustomed to eating rice and cannot be easily replaced by other food ingredients. This study aims (i) to know the effect, and (ii) to get the best dose of granule organic fertilizer on the growth and yield of rice plants of Ciherang Varieties on lebak lowland. This research was conducted in Harusan Village, Amuntai Tengah District, North Hulu Regency, from February to May 2011. This study used a single randomized block design (RBD). The factors studied were 5 levels of granule organic fertilizer, namely: g0: 0 ton.ha-1, $g_{1}: 1$ ton.ha-1 equivalent to or $8.571 \mathrm{~g}$ per clump or $0.3 \mathrm{~kg}$ per plot. $\mathrm{g}_{2}: 2$ ton.hal is equivalent to $17.142 \mathrm{~g}$ per clump, or $0.6 \mathrm{~kg}$ per plot. $\mathrm{g}_{3}: 3$ ton.ha $\mathrm{h}^{-1}$ is equivalent to $25,714 \mathrm{~g}$ per clump, or $0.9 \mathrm{~kg}$ per plot. $\mathrm{g}_{4}: 4$ ton. $\mathrm{ha}^{-1}$ is equivalent to $34.285 \mathrm{~g}$ per clump, or $1.2 \mathrm{~kg}$ per plot. The factors studied were as much as granule organic fertilizer. The results showed that the treatment of granular organic fertilizer dosage did not affect plant height, many tillers, but the treatment had a significant effect on the number of filled grain per clump. The treatment of granulated organic fertilizer dosage of 2 tons. ha ${ }^{-1}$ is equivalent to $17.142 \mathrm{~g}$ per clump, which is the best dose of the number of filled grain per clump.

Keywords: Paddy, fertilizer, granul, organic, wetland.

\section{PENDAHULUAN}

Padi merupakan bahan makanan yang menghasilkan beras. Bahan makanan ini merupakan makanan pokok bagi sebagian besar penduduk Indonesia. Meskipun sebagai bahan makanan pokok, padi dapat digantikan atau disubtitusi oleh bahan makanan lainnya, namun padi memiliki nilai tersendiri bagi orang yang terbiasa makan nasi dan tidak dapat dengan mudah digantikan dengan bahan makanan yang lain. Itulah sebabnya padi menjadi sangat penting bagi bangsa 
Indonesia dan masalah pertanian khususnya pengadaan bahan pangan merupakan masalah yang selalu dihadapi pemerintah, sehingga senantiasa mendapat prioritas utama (Kanisius, 2003 dalam Norhasanah, 2009).

Rawa lebak dikenal memiliki sifat dan watak tanah sulfat masam yang mempengaruhi pada sifat fisik, kimia dan biologi tanah. Sifat fisik berpengaruh pada warna tanah, kematangan tanah, dan permeabilitas tanah (sifat tekstur, struktur dan konsistensi tanah). Sifat kimia tanah akan berpengaruh pada kemasaman tanah $(\mathrm{pH})$, salinitas (kegaraman), dan ketersediaan hara. Sedangkan sifat biologi tanah berpengaruh pada bakteri perombak bahan organik, bakteri pereduksi sulfat dan besi serta bakteri pengoksidasi besi dan pirit (Noor, 2004).

Hasil analisis tanah lahan rawa lebak di Desa Harusan Kecamatan Amuntai Tengah Kabupaten Hulu Sungai Utara menunjukkan nilai $\mathrm{N}$ 0,154 termasuk kriteria Sangat rendah, Nilai $\mathrm{P}$ Total $\left(\mathrm{mg} / 100\right.$ gr $\left.\mathrm{P}_{2} \mathrm{O}_{2}\right)$ adalah 57.106 termasuk kriteria tinggi. Nilai P-Bray 1(ppm $\left.\mathrm{P}_{2} \mathrm{O}_{5}\right) 4.145$ termasuk kriteria sangat rendah, Nilai K total $\left(\mathrm{mg} / 100 \mathrm{gr} \mathrm{K}_{2} \mathrm{O}\right)$ 15.64 termasuk kriteria rendah. Nilai $\mathrm{Fe}$ (ppm) 24.80 termasuk kriteria tinggi, dan Nilai $\mathrm{pH} \mathrm{H}_{2} \mathrm{O} 5.45$ termasuk kriteria agak masam (Balitra, 2011)

Dari hasil analisis tanah lahan rawa lebak di Desa Harusan Kecamatan Amuntai Tengah Kabupaten Hulu Sungai Utara tersebut dapat disimpulkan perlu adanya peningkatan pemberian pupuk organik granul untuk meningkatkan kesuburan tanah.

Hasil analisis pupuk organik granul menunjukan ketersediaan $\mathrm{C}$ organik yang

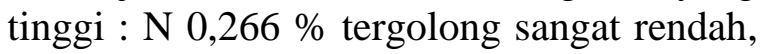
C.Organik $6,95 \%$ tergolong tinggi, $\mathrm{pH} \mathrm{H}_{2}$ O6,74 tergolong netral (Balitra, 2010). Fungsi utama penggunaan pupuk organik granul adalah menyediakan $\mathrm{C}$ Organik dan mikroorganisme menguntungkan (Dhani, 2010).

Menurut Dhani (2010) Kelebihan penggunaan pupuk organik granul praktis dapat diaplikasikan sebagai pupuk dasar, menghemat pemakaian pupuk kimia pabrik (anorganik) sebesar 35-50\%, dapat dipakai sebagai pupuk dasar dan atau pupuk susulan.

Produksi padi di kabupaten Hulu Sungai Utara tahun 2008 sebesar 161.343 ton.ha ${ }^{-1}$ (angka sementara Propinsi) diperoleh dari luas panen 28.629 ha. Pencapaian produksi padi tahun 2009 sebesar 174.842 ton.ha ${ }^{-1}$ (angka sementara Provinsi) Produksi tersebut diperoleh dari luas panen 29.833 ha (Dinas Pertanian, Tanaman Pangan dan Hortikultura Kabupaten Hulu Sungai Utara, 2009).

Dari data tersebut diketahui produksi padi tahun 2009 terjadi kenaikan sebesar 13.499 ton.ha ${ }^{-1}(8,37 \%)$ dibanding tahun 2008. Kenaikan ini disebabkan adanya peningkatan luas panen diikuti dengan peningkatan produktivitas namun pada tahun 2010 diperkirakan devisit karena faktor alam namun mengenai angka tepatnya belum di keluarkan (Dinas Pertanian, Tanaman Pangan dan Hortikultura Kabupaten Hulu Sungai Utara, 2009).

Penelitian ini bertujuan (1) Mengetahui pengaruh pertumbuhan dan hasil tanaman padi terhadap pemberian pupuk organik granul pada lahan rawa lebak. (2) Mengetahui dosis pupuk organik granul yang terbaik untuk pertumbuhan dan hasil tanaman padi pada lahan rawa lebak.

\section{METODE PENELITIAN}

\section{Tempat dan Waktu}

Penelitian ini dilaksanakan di Desa Harusan Kecamatan Amuntai Tengah, Kabupaten Hulu Sungai Utara. Pada bulan Pebruari - Mei 2011.

\section{Bahan dan Alat}

Bahan yang digunakan pada penelitian ini adalah lahan rawa lebak, benih padi varietas Ciherang, pestisida nabati atau alami dan pupuk organik granul.

Alat yang digunakan antara lain alat pembersih lahan dari gulma, meteran, timbangan, hand sprayer, tugal, alat-alat tulis, plastik dan alat foto.

\section{Rancangan Percobaan dan Analisis data}

Penelitian ini merupakan percobaan yang dilakukan di lapangan dengan rancangan perlakuan faktor tunggal dengan 
menggunakan rancangan lingkungan yaitu Rancangan Acak Kelompok (RAK) dengan pengelompokkan berdasarkan tinggi bibit, yaitu kelompok I : $26 \mathrm{~cm}$, kelompok II : 23 $\mathrm{cm}$, kelompok III : $20 \mathrm{~cm}$, kelompok IV : 17 $\mathrm{cm}$. Faktor yang diteliti adalah pemberian pupuk organik granul $(\mathrm{g})$ sebanyak 5 taraf yaitu : $\mathrm{g}_{0}: 0$ ton.ha ${ }^{-1}, \mathrm{~g}_{1}: 1$ ton.ha ${ }^{-1}$ setara dengan atau $8,571 \mathrm{~g}$ per rumpun atau $0,3 \mathrm{~kg}$ per petak. $\mathrm{g}_{2}: 2$ ton.ha ${ }^{-1}$ setara dengan 17,142 $\mathrm{g}$ per rumpun, atau $0,6 \mathrm{~kg}$ per petak. $\mathrm{g}_{3}: 3$ ton.ha ${ }^{-1}$ setara dengan $25,714 \mathrm{~g}$ per rumpun, atau $0,9 \mathrm{~kg}$ per petak. $\mathrm{g}_{4}: 4$ ton.ha ${ }^{-1}$ setara dengan $34,285 \mathrm{~g}$ per rumpun, atau 1,2 $\mathrm{kg}$ per petak.

Masing-masing percobaan diulang sebanyak 4 kali ulangan, sehingga terdapat 20 petak satuan percobaan dan setiap satuan percobaan terdiri dari 2 tanaman sampel pada tiap petakan.

Pengamatan dilakukan terhadap tinggi tanam, umur tanaman, jumlah gabah isi per rumpun, panjang malai,

\section{HASIL DAN PEMBAHASAN}

\section{Tinggi Tanaman}

Berdasarkan hasil analisis ragam untuk tinggi tanaman umur 21, 28, 35, 42 dan 49 HST menunjukkan bahwa perlakuan pemberian pupuk organik granul tidak berpengaruh.

\section{Jumlah Anakan}

Berdasarkan hasil analisis ragam untuk jumlah anakan tanaman padi umur 21, 28, 35, 42 dan 49 HST menunjukkan bahwa perlakuan pemberian pupuk organik granul tidak berpengaruh.

\section{Gabah Isi Per Rumpun}

Berdasarkan hasil analisis ragam jumlah gabah isi per rumpun menunjukkan bahwa dosis pupuk organik ganul memberikan pengaruh nyata terhadap jumlah gabah isi per rumpun.

Tabel 1. Hasil uji rata-rata jumlah gabah isi rumpun padi terhadap perlakuan pemberian pupuk organik granul

\begin{tabular}{cc}
\hline Perlakuan & Jumlah gabah isi rumpun \\
\hline $\mathrm{g}_{0}$ & $1675,12 \mathrm{a}$ \\
$\mathrm{g}_{1}$ & $2123,41 \mathrm{ab}$ \\
$\mathrm{g}_{2}$ & $2476,87 \mathrm{~b}$ \\
$\mathrm{~g}_{3}$ & $2349 \mathrm{~b}$ \\
$\mathrm{~g}_{4}$ & $2209,37 \mathrm{~b}$ \\
\hline
\end{tabular}

Keterangan : Nilai rerata yang diikuti huruf superscrift yang sama menunjukkan tidak berbeda berdasarkan DMRT pada taraf $5 \%$

Dari Tabel 1 menunjukkan bahwa perlakuan $\mathrm{g}_{0}$ dan $\mathrm{g}_{1}$ tidak berbeda, tetapi perlakuan $\mathrm{g}_{2}$, $\mathrm{g}_{3}$ dan $\mathrm{g}_{4}$ berbeda dengan perlakuan $\mathrm{g}_{0}$, Sedangkan perlakuan $\mathrm{g}_{1}, \mathrm{~g}_{2}, \mathrm{~g}_{3}$ dan $\mathrm{g}_{4}$ tidak berbeda, dengan perlakuan dosis yang lebih efisin didapati pada dosis 2 ton.ha ${ }^{-}$ ${ }^{1}$ sama dengan $17,142 \mathrm{~g}$ per rumpun.

Dari tabel hasil uji rata-rata diatas dapat dilihat perlakuan dosis $\mathrm{g}_{2}$ menunjukkan hasil dalam budidaya tanaman, juga dapat menghasilkan ion-ion $\mathrm{H}^{+}$yang dapat menyebabkan tanah menjadi makin masam. Kemasaman tanah pada lapisan permukaan oleh kegiatan biologis dan kegiatan pemupukan (seperti nitrifikasi N, oksidasi S dan sebagainya). Kation-kation dalam yang lebih baik dari perlakuan dosis $\mathrm{g}_{0}, \mathrm{~g}_{2}$ dan pada perlakuan dosis $\mathrm{g}_{3}, \mathrm{~g}_{4}$ menunjukkan penurunan hasil gabah isi tetapi tetap lebih baik dari perlakuan $\mathrm{g}_{0}, \mathrm{~g}_{2}$ sehingga didapat dosis yang optimal adalah $\mathrm{g}_{2}$.

Kegiatan biologi (tanaman dan mikro organsime tanah) pada lapisan olah tanah

larutan akan bergerak ke bawah dalam profil tanah, yang sekaligus dapat mengangkut anion-anion yang mudah larut, seperti NO3$\mathrm{SO}^{-}, \mathrm{Cl}^{-}$, dan sebagainya. Ketidaksuburan tanah masam daerah tropis, atau rendahnya produktivitas tanah masam daerah tropis, pada umumnya di samping oleh faktor 
kemasaman tanah juga disebabkan karena $\mathrm{P}$ rendah dan daya fiksasi fosfor yang tinggi, kemudian daya keracunan oleh ion $\mathrm{Fe}$ dan $\mathrm{Al}$ yang tinggi, KTK rendah, kejenuhan basa (terutama $\mathrm{Ca}$ dan $\mathrm{Mg}$ ) yang rendah, dan hasil pelapukan bahan organik tercuci. Keracunan tanaman oleh ion Al merupakan penyebab ketidak suburan tanah-tanah masam (Absori, 2009).

Menurut Suhardjo (1993), bahan organik dapat meningkatkan kesuburan tanah secara alami. Berbagai hasil penelitian menunjukkan bahwa pemberian bahan organik dapat mendukung perbaikan sifat fisik, kimia, dan biologi tanah, yang selanjutnya dapat meningkatkan perbaikan kualitas lahan. Bahan organik yang diharapkan mampu mendukung kualitas perbaikan kondisi tanah yang telah miskin akan kandungan bahan organiknya dapat berasal dari berbagai tumbuhan yang mengandung unsur-unsur yang dibutuhkan tanaman. Jadi pemberian pupuk organik granul sebagai bahan organik dapat menambah unsur hara didalam tanah agar ketersediaan unsur hara dalam tanah dapat menjadi lebih baik bagi tanaman.

Dari hasil analisis ragam menunjukkan bahwa perlakuan pemberian pupuk organik granul terhadap variabel terhadap tinggi tanaman dan jumlah anakan tidak berpengaruh pada umur 21, 28, 35, 42 dan 49 HST. Hal ini dikarenakan bahwa kandungan unsur hara $\mathrm{N}$ yang terdapat pada tanah rendah. Kandungan unsur hara $\mathrm{N}$ pada pupuk organik granul termasuk sedang sebesar $0,266 \%$. Sehingga belum mencukupi untuk memenuhi kebutuhan unsur hara $\mathrm{N}$ sehingga tanaman dapat dikatakan kekurangan unsur hara $\mathrm{N}$, dari diskripsi padi varietas ciherang tinggi tanaman antara 107-115 cm. Sedangkan pada hasil penelitian hanya menunjukkan tinggi tanaman maksimal 93 $\mathrm{cm}$ hal ini menunjukkan bahwa tanaman tersebut masih kekurangan $\mathrm{N}$ untuk pertumbuhan.

Pada masa generatif pengamatan variabel jumlah gabah isi per rumpun menunjukkan pengaruh nyata terhadap pemberian pupuk orgaik granul pada tanaman padi (Oryza sativa L.) Varietas Ciherang pada lahan rawa lebak. Hal ini didukung kondisi air dalam kering macakmacak sehingga proses dekomposisi dapat berlangsung dengan baik dan penyerapan unsur hara oleh akar khususnya kandungan unsur hara $\mathrm{P}$ dan $\mathrm{K}$ dapat lebih optimal. Sehingga memberikan pengaruh terhadap jumlah gabah isi per rumpun.

\section{KESIMPULAN}

Perlakuan dosis pupuk organik granul tidak berpengaruh terhadap tinggi tanaman, banyak anakan, tetapi perlakuan berpengaruh nyata pada jumlah gabah isi per rumpun. Perlakuan dosis pupuk organik granul 2 ton.ha ${ }^{-1}$ setara dengan 17,142 g per rumpun merupakan dosis terbaik terhadap jumlah gabah isi per rumpun.

\section{DAFTAR PUSTAKA}

Absori Firkah. 2009. Tanah masam dan pengapuran. http/www. Firkahal absori@gmail.com.

Balitra. 2010. Laboratorium Tanah, Tanaman dan Air. Analisis Pupuk Organik Granul.

Balitra. 2011. Laboratorium Tanah, Tanaman dan Air. Analisis Tanah Rawa Lebak Desa Harusan Kecamatan Amuntai Tengah.

Dhani. 2010. Pupuk organik granul. http/www. Dhani com. Diakses tanggal 16 Januari 2011.

Dinas Pertanian dan Tanaman Pangan Kabupaten Hulu Sungai Utara, 2009. Laporan Tahunan 2009. Dinas Pertanian.

Noor. M. 2004. Rawa Lebak: Ekologi, Pemanfaatan, dan Pengembangannya. PT. Raja Grafindo Persada. Jakarta.

Norhasanah. 2009. Pengaruh teknik pengolahan tanah dan pemupukan terhadap pertumbuhan dan hasil padi di lahan sawah studi kasus di Desa Bakti Kabupaten Hulu Sungai Tengah. 
(Tesis) Program Pasca sarjana Universitas Lambung Mangkurat.

Banjarbaru.

Suhardjo, H. 1993. Tanah Gambut. Puslit

Tanah dan Agroklimatologi. Bogor. 